\title{
ESTONIAN FOLK MUSIC LAYERS IN THE CONTEXT OF ETHNIC RELATIONS
}

\section{Ingrid Rüütel}

\section{Style and melody types in the comparative folk music research}

A comparative study of folk music is relevant from the aspect of both the style

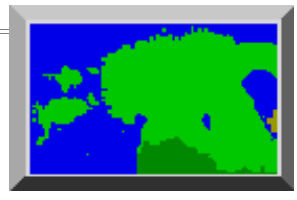
and the melody types. Style is specified as a complex of musical features and determined by their quality and structure. We may define national, regional and historical styles, genre peculiarities, performing styles etc. Style as a complex phenomenon is related to a complex of causes while in certain causal relations different factors may dominate. Alongside with historical, regional and functional factors style peculiarities are determined by the structure of language.

Thus, the musical form of Estonian and Balto-Finnic runo-song tunes, especially the length of the basic structural unit, shows foremost the stage of historical development, while the length of the melody has a strong positive correlation with the melodic range (Rüütel 1986). In our case the horisontal as well as vertical widening of song tunes was mainly parallel. Deviations from such a general regularity seem to result primarily from the peculiarities of the function and the genre of a song. The melody-movement is particularly related to the speech intonation, at least in more ancient tune-layers. Rhythm and some melody attributes may be conditioned by the performance which in its turn is related to the genre and function of the song (e.g. the North-Estonian swing-song tunes with their very specific rhythmic and melodic structure).

In actual development of folk music all the factors influencing the genesis and evolution of musical phenomena intertwine or mix and any music forms a symbiosis of them all.

Beside the study of style, melody types as phenomenal units of folk music constitute a separate aspect of research in folk music studies. All folklore phenomena, including melodies, disseminate as variants in space and time. A tune type forms of a complex of its variants (tune samples) united by a common content and the basic qualities of form (for details see: Rüütel 1986). Its basic quality is expressed in the common invariant which as a rule is preserved in the samples of one and the same melody type.

The genetic ties of folk music are best expressed by the melody types but it must be taken into consideration that, on the one hand, outwardly very similar melodies may derive in different locations independently; on the other hand, the melodies of common genesis may acquire different shapes above recognition while spreading in time and space. Therefore the establishment of typologically related tune-families requires a thorough typological research. The conclusions drawn from different occasional examples can not give reliable results. It is just the same as to compare externally similar words in different languages without any knowledge about their origin and etymological background.

The differentiation of melody types, however, especially in archaic music, is rather complicated. It demands a very exact and detailed structural analysis and special methods. This is the reason why the problem of musical typology of folk melodies on international scale has not been solved yet. Several attempts have been made, based on different material and while using different methods (Ling, Jersild 1965; Elschekova 1966; Chekanowska 1977; Pelinski 1981 et al). Still, universal methods suitable for all musical cultures have not been created. May be it is eventually impossible, whereas different musical cultures are so diverse. 
The original computerised method for distinguishing melody types, worked out at the Folklore Department of the Institute of Estonian Language, is based on modelling the melody on the basis of the melodic context (see: Rüütel 1981; Rüütel, Haugas 1990). It enables to distinguish typologically related melody-groups as well as to discover their possible relations and overlaps. The most efficient way for solving these problems appeared to be the cluster analysis method, which permitted to group tunes under study round fixed centres (melody models) (Rüütel 1979). Such grouping (clusterization) corresponds to the dialectic notions of "type" and "variant" in the folklore theory according to which all variants of a folklore (or folk music) phenomenon (type) share the common basic form, from which they may differ in detail, having at that a common invariant (Rüütel 1986). Special studies have shown that such an invariant of old Estonian runo-tunes is expressed by the system of basic tones of a melody which is formed by the given scale degrees in a given syntactic position of the melody (Rüütel 1980). Such an invariant reveals itself only after the analysis of tune samples of an established melody-type and contains the pitch values of only a part of syntactic positions of a melody (the most stable ones).

In addition to the invariant, every melody-type is also characterised by a certain basic form - the normative model which is formed on the basis of the most probable pitch value (pitch degree) of every syntactic position of the melodies in the given typological group. Mathematically, the normative model is the mode of the multidimensional distribution of melodies of a given melody group. Such normative models (centres) can be found with the help of a statistic analysis of the melodic context (Rüütel 1986 A). The research has shown that the modelling of melodies on the basis of the melodic context proves to be the most efficient method of distinguishing normative models. We have worked out an iterative algorithm ("Centre") for the preliminary establishment of the initial centres of classification, considering the multidimensional qualities of the objects under study (Rüütel, Haugas 1990). It enables to create melody models which serve as the basic forms of certain melody types. Another iterative algorithm ("Cluster") enables to compare all the tune samples with all the models (centres), to find out the model which any tune sample is the nearest to and classify all of them accordingly into clusters which in our case correspond to the typological groups of melodies. After the first classification the centres are checked up and corrected (if it is needed) according to the concrete tune material, then the new, more specified clusterisation is carried out, centres are corrected again, etc. Such an iterative analysis lasts until the system becomes stable. Finally most of the tunes usually appear to belong to certain clusters, part of the tunes remain on the borders of two or more clusters and part of them do not belong to any of them. Then a distance matrix is calculated which reveals the relations between separate centres and enables to discover interrelations of the typological system. A general structural model of a typological group may be constructed which serves as the grammar of the tune-group, fixes its syntactical rules and enables to derive all the variants of a given melody-type, including those which are not presented in the initial material (see: Rüütel 1986 B). Later, the correlations between the established tune types and other features (region, song-genre, rhythmic pattern, etc.) may be calculated. While studying Estonian one-line refrainless tunes it appeared, for example, that the tune-types are the most closely related to a geographic region, and less to a song-genre. It is caused by the fact that most of the tunes served as general tunes for different song-genres. Yet, it appeared that a part of melody-types are characterised by clearly distinguishable genre peculiarities. So far the above described method has been used for studying the melody types of Estonian, Karelian and Ingerian one-line refrainless song-melodies, Estonian one-line refrain-tunes, and for studying a part of Estonian two-line melodies (about 2000 tune samples in total). 


\section{Possibilities and difficulties in interpreting folk music from ethnic aspects}

The comparative typological study of folk tunes, complemented with the results of style analysis and with the archaeological and linguistic data, may serve as the basis for interpreting folk music from ethnic aspects, despite of the inevitable suppositional character of such interpretations (Rüutel 1990). When interpreting folklore phenomena from an ethnic aspect, we encounter several difficulties. Thus, it is not always clear whether similar phenomena yield evidence - not only stylistically but also typologically - of an ethnic unity (either primary or more recent, based on assimilation) of their bearers, or whether they indicate an autonomous dissemination of cultural phenomena - the so called cultural loans, which surpass ethnic as well as language barriers. In fact, it is a universal problem including both the material and the intellectual culture.

It is possible to distinguish certain genres of folklore which pass the language barriers easily, and others which are related to an ethnic group and language more tightly. The former can be called ethnically mobile, the latter ethnically stable ones. The first group includes primarily non-verbal phenomena, like dances, which are not related to language, and tales, which can be translated rather easily because they are not restricted by poetic forms as songs are. Ritual songs are ethnically very stable due to their elaborate ethno-social context, as are also lyrical songs due to their imageoriented structure, whereas the narrative songs are more autonomous and easier to translate.

Ethnically the most mobile part of music is, no doubt, instrumental music. As for song melodies, the song melodies of newer style are more mobile due to their more independent musical expression and universal form. Archaic song tunes are by far more closely related to the speech intonation and structure of a particular language; their ethno-social context is also more elaborate. But in archaic music, because of limited means of expression, we must consider the possibility of autonomous genesis of typologically close phenomena.

Another problem aggravating folk music research and its ethnic interpretation is uneven occurrence of archaic cultural phenomena due to sporadic retention. This in turn is connected with the different speed of development of individual cultural areas and with different external influences. Alongside with the newer song layers the Estonians as well as the Balts have preserved rather well their archaic song genres and music styles (Lach 1929; Bendorfs 1981; Kirsite 1985). Much that is archaic has been preserved in the music of different Finno-Ugric and Slavic peoples. But we have no clues to the contemporary early Germanic, including Scandinavian music whose oldest music layers date probably just from the Middle Ages.

Relations between a culture and its ethnic preservation are also complex. The most stable identifier of an ethnos is its language. When the language disappears, the ethnos as a phenomenon disappears usually as well, although the latter may be preserved as an anthropological substratum. Some elements of its culture may be preserved in a cultural dialect of the assimilative nation as a cultural substratum. Such substrata of Finno-Ugric elements has been discovered in Russian folk music (e.g. Macievsky 1980; Rüütel 1987). The opposite case is the situation where the ethnos has preserved its language but has passed over to a foreign musical language which is rather usual.

In comparison to archaeological objects, the ethnological interpretation of folklore phenomena is more difficult caused by the fact that a tradition may change in the course of time, and the primary area of distribution of a certain oral culture may change as well, while these phenomena may sometimes preserve better in their new location than in their place of origin. Nevertheless, the old layers of Estonian folk music have been preserved, if at all, in a surprisingly conservative form. New music layers have appeared alongside of them, leaving their structure essentially intact. The extreme conservatism of archaic musical phenomena has also been noted by musicologists from Latvia, Lithuania and elsewhere. 
Thus, the inevitable suppositional character of ethnic interpretations does not mean that ethnic research in folk music has no perspective. But it should be based on the distinguishing of folk music layers, styles and melody types; on the specification of alteration principles, ways of development and other internal processes; and on the concrete geographical study of melody types and style phenomena. The results of musical analysis should be combined with textual, ethnographic, linguistic and archaeological data.

\section{Historical strata of the Estonian folk music}

The Estonian folk song is usually divided into two main historical-stylistical strata: the runo-songs (songs in runo-verse form, also called Kalevala-metre songs, alliterative songs etc.) and the newer songs with an end-rhyme and strophic form. Both are characterised by a special musical style. The first one belongs to the old Balto-Finnic culture and derives probably from the last millennium B.C., the latter one is related to the European traditional songlore of the last centuries.

Besides runo-songs (which are represented in the Estonian tradition first of all by lyrical songs and by working songs, ritual songs, game songs, etc., less by the narrative ones) there exist a number of ancient non-runo genres which are characterised by a special intonation mode depending on the contents and function and which do not denote music in the accustomed meaning. However, the intonation mode typical to these genres still deviates from the ordinary speech; the speech intonation is used only as one potential means of expression alongside with other intonation patterns.

\section{Ancient non-runo vocal genres}

Here belong:

1. Cries, shouts, calls with the function to signal, communicate or co-ordinate rhythm (herding and hunting calls, signals for co-ordinating working processes, ritual calls, etc.) ( see: e.g. Vilkuna 1946; Vissel 1986; Rüütel 1994: 28);

2. Imitations of natural sounds: either natural or artificial. The first have generally practical, utilitarian function (they are used by hunters for alluring birds or animals even today); the others might have had primarily magic significance and were later used for amusement (e.g. the so called birds' songs containing a poetic text whereas the respective bird sounds are imitated both as phonic compositions and by intonation). Here belong also "conversations" of animals, birds, as well as spinning wheels, carts, church bells etc. The significant expressive means alongside with imitation is the tonal and temporal contrasting of certain phrases or words (high - low, fast - slow) (see: e.g. Rüütel 1994: 28-31).

3. Incantations and spells used for influencing and inducing natural forces, animals or human beings, for inciting the working process, for healing, sauna charms, etc. which occur as verse incantations in Estonia. While in Finland and Karelia they are predominantly in the Kalevala metre, then in Estonia a large part of them are either in the accentual metre or in the heterosyllabic free verse. These were performed either as a half-whispering mutter, a recital with free rhythm (halfsinging, half-speaking), as a monotonous scansion with fixed measure, or while shouting (Rüütel 1994: 31-36).

4. Laments (death dirges, wedding laments, later also lamentations for recruits and for other occasions). In Estonia they preserved longer mostly in Setu (Pino, Sarv 1991; Pino, Sarv 1992; Sarv 
1986). Death dirges are noted also in other parts of East Estonia. Laments were known also by the Karelians, Vepsians, Votians, Izhorians and other Finno-Ugrians. A lament performed in a genuine situation represents an act of wailing through weeping, while the intonation of a speech phrase intervenes with weeping. A lament verse (or a longer period) is followed by the actual weeping (Rüütel, Remmel 1980). The text contains traditional runo-song patterns, images and motifs but improvisation is of much greater importance here, it involves both the contents and the form of the text as well as the structure of the melody.

5. Songs in fairy tales (see: Salve, Sarv 1987). Besides explicit songs which are dissimilar in verse metre and musical characteristics, there occur also recitative monologues and dialogues which hardly differ from the rest of the text (as is the case with tales and shamanistic performances of Siberian peoples).

6. Children songs ( see: e.g. Tampere 1958: 139-201; Rüütel 1994: 33-40). Hereto refer 1) songs performed for children (lullabies or simple asemantic lullings, nursery songs performed with respective gestures and movement to amuse the baby, incantations for children, songs in a restricted sense); 2) children's own repertoire (traditional addressings to birds, animals and objects of nature with an initial magic background, banter words and other jesting verses, songs in a restricted sense etc. ).

7. Chain songs (which initially had a magic background but have later become a part of children songs) (see: e.g. Tampere 1958: 204; Rüütel 1994: 41).

Having specific purpose and functions, all these genres evolved probably earlier than runo-verse, existed alongside with runo-songs and have partly preserved even longer. Due to their practical function they may sometimes emerge even nowadays (e.g. improvised lullings, shouts for coordinating working rhythm, herding and hunting calls, etc.). Regardless of certain tendencies to interfuse with runo-songs and assimilate into the runo-verse form ( Finnish and Karelian charms and chain song texts are mostly in the Kalevala-metre) these genres still maintained autonomy and specific characteristics in the Estonian tradition both in function as well as in expression, and this concerns both the text and the music (resp. mode of intonation).

These genres occur also by those Balto-Finnic peoples who do not know the Kalevala-metre songs. They represent rather universal phenomena in archaic cultures. In many cases the question arises whether we are dealing with songs altogether, or rather with phenomena preceding songs? What is a song after all? This conception has different interpretations in different cultures.

The Balto-Finnic peoples regard as song (laulu) in general a vocal genre which consists of a poetic text and a melody with a certain structure. The word laulu is common to all Baltic Finns who know the runo song, and to Livonians (by whom the runo-song form is not documented). This conception expresses the consistency of poetic texts and melodies. Runo-songs have always been performed while singing but originally there existed no special word for denoting the melody (the Estonian word viis is of Germanic origin).

Traditionally laments, spells, calls, herding vocalisms, wedding shouts etc. were not referred to as songs, nor were their performance called singing. The same applied to children and chain songs, if these were presented corresponding to the ordinary speech style, as a recitative with free rhythm or as a scansion in strict measure but without any insistent melody. The discussed vocal genres were usually designated by special, often descriptive and original linguistic expressions, as a rule. The same word stems were used for referring to the performing of these genres ( huikama, hellatama, hõiskama, itkema, lausuma, sõnama etc). 
Still, the verb laulma is used for lullabies and even for asemantic lulls, and also for the song-like intermediate parts in fairy tales, apparently because they oppose to the prose text, distinctly contrasting in structure with an obvious artistic or other special intention. The sounds of certain birds and their imitations are also called songs.

On the other hand, there is no clear distinction between the song and other vocal genres. Both in text and music of the discussed ancient genres the various stages of fixedness and development (songfulness) are rather different. Regarding the poetic text, some of these genres lack words altogether, they are performed on a phoneme or on asemantic syllables; the others do contain words but without any definite poetic structure. They remain in-between speech and poetry, being at the same time most improvisational. Finally, hereto belong texts with traditional poetic expression and invariable structure, although the structural freedom and improvisation is of greater significance than in runo songs. In comparison with the fixed norms of the runo song form (the 8-syllable verse based upon the trochaic structure of a quantitative metre), the length of verses is more variable both in different genres as well as in the one and the same specimen. Instead of a quantitative metre we can find here an accentual one (with a fixed or variable number of stressed syllables and non-fixed number of unstressed syllables), and also a free metre and rhythm corresponding to the speech rhythm.

The relations between text and melody can be likewise diverse. Even the poetically established texts with invariable structure are in general not accompanied by a melody in the accustomed meaning.

Nevertheless, it seems that the Balto-Finnic popular conception of a song has not been too particular about the musical characteristics. E.g., herding calls have developed into vocalisms, which are melodically among the most advanced vocal genres in the Balto-Finnic song tradition. Regardless of that, they are not called "songs", nor is their performance called "singing", but instead descriptive terms are used, derived from asemantic syllables (see: Vissel 1986). It is probably explained by the free structure of both the text and the melody.

The above discussed ancient non-runo vocal genres are based upon specific modes of intonation which are not characteristic of runo-songs, or which occur in runo- songs in a different way. Hereto refer:

1. Monotonous intonation based on permanent repetition of the same pitch level;

2. Calls, shouts, rhythmic recitations, etc., based on permanent contrasting of two pitch levels where the higher degree corresponds to the stressed syllables and the lower one to the unstressed ones (permanent opposition of two degrees occurs also in rhythmical recitings where the lower degree is repeated or both degrees are repeated);

3. Repetition of the step-by-step descending movement; descending glides are also very typical but they occur usually in combination with other intonational modes;

4. Imitation of natural and other sounds;

5. Tonal and temporal contrasts (two or three phrases are opposed to each other while performed on different pitch levels and (or) in different time);

6. Recitative, speech-like type of intonation corresponding to the intonation of a narrative phrase having the undulating melody contour with a general descending direction. The melodic culmination corresponds to the prosodic one, smaller ascents and descents are connected with the stressed and unstressed syllables of the words as it is characteristic of the Estonian and other BaltoFinnic languages. 
All these types of intonation may be performed either in a more speech-like or in a more song-like way which may also alter during the same performance. Separate samples of discussed genres are based on one of the named types of intonation or on several types intertwined. The last type of the melody construction becomes the main formation basis of the runo song melodies which are characterised by a more developed, a more stable tonal and melodic structure, by a more "musical" intonation and, what may seem somewhat paradoxical - by a narrower tonal range. Examples $1-7$

\section{Layers of the Estonian runo-song tunes}

In the following we do not attempt to give a thorough musical characterisation of the discussed tunes (which exceeds the limits of the current paper) but we shall try to determine the main layers of runo song tunes and discover their genesis in the context of ethnic history.

\section{One-line refrainless melodies of North and West Estonia}

The oldest basic layer of Estonian runo-tunes are represented in one-line refrainless melodies (i.e. melodies corresponding to one verse line of text) of a narrow tonal range (mostly a third or a fourth). They occur mostly in North and West Estonia, including the islands, less in the peripheral areas of South Estonia (see *Map 1).

Among them one can differentiate between tunes with a descending melody-movement (with a possible ascent at the beginning of the melody) based upon the speech-intonation, and tunes with a descending-ascending contour (the so-called Pendelmelodik) which belong as a rule to the swingsongs (primarily women's calendar-ritual songs sung while swinging).

In the mentioned speech-like melodies, and also in the prosodic intonation melodic ascents usually coincide with the stressed syllables of the words and descents coincide with the non-stressed ones (exceptions from such a regularity may mostly take place at the beginning of a melody-line). The pitch culmination of a melody-line corresponds to the prosodic culmination of a phrase (a verse). The melody may follow the norms of the words during a song consistently (though still following the musical norms concerning pitch degrees) but mostly it is represented as a generalised model of the speech-intonation formed as a musical abstraction of the prosodic intonation of the 8-syllable runo-verse (see: Rüütel 1986: 173-180).

In swing-song tunes correlations with the speech-intonation occur less often and the melody often ends with an ascent which is in contradiction with the Balto-Finnic prosody.

The distribution area of the one-line speech-like tunes expands from the North-Estonian coast through Järvamaa and the Pärnu river-basin region to the South-West Estonian coast and the WestEstonian islands (*Map 1).

In the east it spreads through the Kodavere parish up to Setumaa where the described tunes represent the older one-voiced melody-layer (mainly lullabies) (Rüütel 1990). In the Karksi parish (South Estonia) such tunes are met in game songs only. In other parts of South Estonia one-line refrainless speech-like tunes are not typical and occur rather sporadically.

The typological analysis of all one-line refrainless tunes revealed that they can be divided into 40 typological groups (see Table 1) which are associated first of all with geographic regions, less often with particular song-genres (e.g. as was the case with the above mentioned swing-song tunes). The 
majority of tune-types are spread in one, two or three neighbouring counties (e.g. in Harjumaa; Harjumaa, Virumaa and Järvamaa; Virumaa and Tartumaa (Kodavere); Virumaa, Järvamaa and Kodavere, etc.). Common distribution area of certain tune-types joins the East-Harjumaa coast with the West-Estonian islands, or with the south-western coast and islands (the Audru and Tõstamaa parishes, Kihnu island). Less often a tune-type is spread all over the territory from East Estonia to West Estonia. In the latter case we are merely dealing with a more general peripheral distribution. E.g. samples of the type 29 can be found in all the main distribution areas of the tune-layer under discussion. Here belong also the Karksi game song tunes and a number of the Setu lullaby-tunes. To this group belong in general a considerable amount of lullabies of different regions which reveal some specific traits typical of the melodies of ancient improvisatory lulls sung on asemantic syllables, being probably pre-runo ones (see: Rüütel 1980).

The speech-like melody-types with a descending contour usually do not belong to any concrete song genre but can be specified as polyfunctional, the so-called general tunes used in different song genres. Formed on the basis of the speech-intonation, they were suitable for all songs which were recited as spells, charms, for communicating tidings, requests, edifications, commands or simply as talk, narrative, etc. Such melodies were more closely combined with the structure of the text than its content. Due to the variability of the ancient tunes they could easily be adapted to different performing situations, concrete texts and rhythms (within the form of 8 metrical units). In verse lines which contain three-syllable words (the so called murrelmasäkeet) word stresses are normally preserved while singing and musical accents are subordinated to word stresses (although the dynamic stresses are rather weak as they are weak also in the Balto-Finnic languages). ${ }^{*}$ Example 8. Wedding song

The same tune-type can be applied to all song genres and it often appeared that a singer actually had only one melody for all her songs. Yet, statistical analysis of the tune-layer under discussion revealed the preference of older song genres, such as wedding songs, ancient epic songs, calendarritual songs, etc. To the latter belong also the swing-songs. But due to the special way of performing (singing while swaying on a big swing) and because the songs tried to be in accordance with the rhythm of swinging, their melodies developed in a special way. The prolongation of descent of each metrical foot (i.e. each even syllable-note) was accompanied by melodic figurations as well as modifications in the melody-contour (ascending motif, phrase and line endings) which contradict with the speech-intonation. It led to the formation of a specific type of swing-song tunes. Their distribution area was noticeably narrower than that of descending speech-like tunes being restricted with Järvamaa and the adjacent parishes of Harjumaa and Virumaa (*Map 2). *Example 9. Swing-song

Despite of certain typological differences the discussed speech-like melodies were rather similar in their inner structure having mostly the same stable system of basic tones. These tunes start on a higher degree of the scale or reach it in the 2nd or 3rd metrical unit, descend (usually into the 2nd degree) in the 4th unit; then a new rise (often lower than in the first half of the melody) follows and the melody descends through the 2 nd degree into the tonic (which it reaches as a rule in the 7 th metrical unit) (see: Rüütel 1986).

The swing-song tunes share a considerably richer spectrum of means of expression which become observable on the level of both the typological and stylistic diversity. They contain the extreme variety of melismas (see: Toi 1982), which are not characteristic of the runo songs in general. At that, the distribution area of separate melody-types is also noticeably narrower than that of the speech-like tunes. So, these swing-song tunes belong to the local peculiarities of a more restricted region and their formation can be considered to be related to the formation of other tribal peculiarities of cultural dialects. 
The archaeological data confirm the beginning of the formation of separate cultural as well as linguistic dialects of the Estonian tribes during the 2nd and 3rd centuries A.D. (i.e. in the later Iron Age). As we are dealing with an ancient song-genre connected with magical background and mythological world view (the swing is considered to be a modification of the world column which joins the lower, central and upper world - see: e.g. Laurinkiene 1984) and an extremely old musical style, therefore it is probable that these tunes evolved during that period or a little later while being developed further and modified in the next period when the two-line modifications were formed. The swinging lost its previous ritual background and preserved in North Estonia as a popular mode of entertainment of village youth up to the end of the last century.

Typologically close to the North-Estonian swing-song tunes are the West-Estonian wedding tunes which reveal the character of shouting (Rüütel 1986; *Map 2). It is difficult to say whether we have here occasional coincidences, or are we facing the influence of the discussed swing-song tunes which might have been introduced by inhabitants from the North.

The distribution area of the above discussed speech-like tunes coincides in general with the earlier persistent agricultural area in Estonia in the I-IV centuries A.D. It is noteworthy that this tune-layer is nearly absent in the regions of the later internal colonisation (e.g. North-West Estonia, etc.) where newer runo-tune layers prevail as well as in the regions which were later populated by outsiders (Ugandi) where an another ancient tune-style developed.

If the swing-song tunes belonged to the cultural peculiarities of more restricted region so the discussed speech-like tune-layer which is extremely unitary both stylistically as well as typologically may be traced back to the North- and West-Estonian cultural unity in the later Bronze Age and earlier Iron Age. The central areas of this archaeological culture were particularly the North-Estonian coast and the islands Muhu and Saaremaa which constituted the most highly developed parts of Estonia at that time. South Estonia developed more slowly and was closely connected with North Latvia which was then populated by the Balto-Finnic tribes. The archaeological culture of North Estonia reveal great similarities to southern and western Finland and to Scandinavia (Jaanits et al 1982). At the same time the archaeological data prove that the Baltic Finns still preserved a noticeable cultural unity with the more eastern Finno-Ugrians (up to the Volga region) while the relations with the Balts were rather weak.

This age coincides also in general with the final stage of the Balto-Finnic linguistic unity, as the dialectic differences became more apparent starting from the 2 nd century A.D. and led to the discernment of separate Balto-Finnic languages. During the first centuries A.D., according to the archaeological data, the main cultural dialects were formed in Estonia concurring with the linguistical dialects which have survived up to this century.

The mentioned North- and West-Estonian cultural and linguistical unity which started to form in the 10th century B.C. and lasted up to the first century A.D. represents a very significant stage in Estonian history, both economically and culturally. Agriculture was developed, cultivating economy became the main branch of economy, the transition to permanent settlement began, people learnt about metal, how to process and use it. Great changes took place in social life - the increase of the role of a man brought along the strengthening of the extended family and the role of other members of the family. Great changes took place also in religious beliefs and rites - transition to cremation, the dissemination of cromlechs and worship stones, etc. Changes in social life created necessary suppositions for the formation of wedding ceremonies. It is plausible that this age, i.e. the final stage of the Balto-Finnic linguistic unity was also the time of formation of the Balto-Finnic runo-song form. The initial centre of the runo-song tradition is considered to be exactly North and West Estonia from where it disseminated to other regions (Kuusi 1963; Virtanen 1987). It has been 
suggested that the most ancient song genres and types evolved here, e.g. harvesting and swinging songs (Tampere 1956), a number of epic songs with mythological content (Tedre 1969: 7-8), etc.

The discussed one-line speech-like melody-layer which represents the most primitive and the most ancient runo-song tune style was probably formed together with the runo-song form. Its distribution area was not restricted by North and West Estonia. It was spread also in Ingeria, being especially characteristic of the Votians who were both culturally and linguistically very close to the North-Estonians (Ariste 1956). Such melodies belong to the main tune-layer of the Votian runosongs. These were polyfunctional tunes used in different genres. Still, the statistical analysis revealed the strongest positive correlation with the more ancient song genres, especially with the wedding songs (Rüütel 1977; Rüütel 1982).

One-line tunes are less characteristic of the Karelia where a newer style prevail. Still, some parallels can be found and the common melodic structure appears also in two-line runo-tunes which have probably survived some relicts of the former one-line ones (Kolehmainen 1977; Rüütel 1986: 164,183).

The basic traits of this tune-layer - one-line form, diatonic scale with a narrow tonal range (a third or a fourth), descending melody contour, step-by-step melody movement based upon syllable-notes, etc. are characteristic also to the melodies of the most ancient song genres of the other FinnoUgrians (Rüütel 1986A), including those who belong to the so called Volga-Ural pentatonic area which was formed probably later ( Vargyas 1981).

\section{Refrain-tunes of South Estonia}

The South-Estonian culture developed since the later Bronze Age and earlier Iron Age quite apart from North and West Estonia. In South Estonia agriculture was less developed at that time; noticeable differences occurred in burial customs and in spiritual culture.

The most archaic song-tune layer of South Estonia is represented first of all by the one-line refrain-tunes, where the basic melody-line, corresponding to the verse-line is followed by a refrain which consists of one or two words. Such a structure is characteristic of working songs, ritual songs and game songs.*Example 10. Kadrilaul

The structural principles as well as a number of concrete melody patterns are similar to the NorthLatvian calendar-ritual and herding song tunes. They constitute a common music layer although the texts are different.

The structural principle where a verse-line is followed by a refrain is characteristic of the Baltic and Slavic old calendar-ritual songs and it is considered to originate from the Baltic-Slavic cultural unity (see, e.g. Zemcovsky 1975). It is not relevant to the older folk songs of the North-Estonians and other Balto-Finnic peoples and is evidently borrowed from the Latvians. But in South Estonia it was even more popular than in Latvia, occurring here in a larger number of song genres. The majority of texts originate from North Estonia (e.g. a number of harvesting and swinging songs, etc.). A lot of wedding song texts are common not only to the different Estonian cultural dialects but to all Balto-Finnic peoples who share the runo-song form and derive probably from the BaltoFinnic cultural unity (Kuusi 1963; Rüütel 1970).

The same melody-type may occur in different song genres but every genre is specified by a special refrain-word (see: Tampere 1956;1958;1960). Refrains in the South-Estonian songs were as a rule original Estonian words with a concrete meaning. The old Balto-Slavic refrain stem lel appears mainly in herding songs (in Setumaa it is popular also in some other genres). 
To sum up, it is evident that in South Estonia the old working and ritual songs have obtained a refrain structure under the cultural influence of the Balts. The melody-layer under discussion is probably formed as the symbiosis of the ancient Balto-Finnic and Baltic culture. Typological and genetic relations between such Latvian and Estonian tunes have also been noticed by Latvian scholars (Bendorfs 1986). If the one-line North- and South-Estonian tunes are compared, it appears that in most cases they are typologically different. Yet, some common types can be found. So, one North-Estonian speech-like melody-type has spread from the Kuusalu parish (the North-Estonian coast) up to the Karula (on the Estonian and Latvian border in the south), and it occurs also in the neighbouring Latvian area (in Vidzeme) (Rüütel 1986: 184). In North Estonia it is refrainless, in South Estonia and Latvia the melody-line is followed by a refrain.

The archaeological data confirm that the Baltic influences upon the South-Estonian culture increased rapidly in the middle Iron Age (II-IV centuries A.D.). It was also the time of differentiation of separate Estonian cultural dialects and it is quite possible that the tune-layer under discussion was formed namely in that period. But let us keep in mind that in the early Iron Age North Latvia was still settled by the Balto-Finnic population and it is possible that they also knew a refrain structure similar to the discussed tune-layer before their assimilation. As it was shown, the latter may be treated as a symbiosis of the Baltic and Balto-Finnic cultures. In the Latvian folk song tradition one-line refrain-tunes are relatively rare in comparison to the two-line refrain-tunes, i.e. those which are based upon two melody-lines both followed by a refrain. This tune-layer which spread in the same old song genres is evidently younger and it is also very popular in South Estonia. Here concrete Latvian loans are much more visible both in song texts as well as in music.

In two-line refrain-tunes different refrains and strophic structures occur. Sometimes Slavic influences may be noticed (Rüütel 1994: 67).

\section{Ancient refrainless tunes of South-East Estonia}

The discussed refrain-tunes spread all over South Estonia and were common also in South-East Estonia. But here, beside the ones mentioned (and the one-line refrainless speech-like tunes which were less represented) a special archaic song tune layer is found. It is also based upon one melodyline but occurs often in a two-line form $\mathrm{AA}_{1}$ with slight deviations in the 2 nd line. As both the above discussed tune-layers, these melodies have also mostly a narrow tonal range (a third, a fourth) which may be enlarged by a subsecond or a subfourth.

This tune-layer differs greatly from other Estonian runo-tunes by its melodic and rhythmic structure which does not correspond to the structure of the runo-verse and is often in contradiction with the speech-intonation (ascending word- and motif-endings, regular musical accents on unstressed syllables and on unstressed positions of prosodic intonation, etc.). Here one can often find also melody-lines longer or shorter than 8 metrical units which do not correspond to the runo-verse structure. The next special rhythmic patterns occur. *Example 11. Lyrical song (*Map 3)

Non-accordances with the song text form are compensated by distributing syllables between two metrical units of the melody, by word repetitions, additional words and syllables, etc. All these means of expression exist as structural norms and may deform the runo verse form beyond recognition.

Roots of this tune layer were evidently formed separately from the runo song tradition, in another cultural context. While later becoming in contact with the Balto-Finnic runo song tradition and complemented by runo-texts this musical style probably assimilated to some extent but melodies 
still preserved their form which caused the above mentioned changes in the song texts. Thus, it can be said that the discussed song layer has been formed as a symbiosis of the Balto-Finnic runo song tradition and some other ethnic culture.

Some tune types and stylistic peculiarities of this tune-layer are spread in more restricted region only - in southern and western Võrumaa and southern Tartumaa (Tampere 1956). Here belong, for example, the polyphonic singing with a special bourdon where the lower accompanying voice performs the text while repeating the same tone (deviating from it in some places, especially in the cadences). *Example 12.

Such a polyphony differs from the Latvian "bagpipe-type" bourdon where the lower voice is performed without any text while prolonging one accompanying tone without interruption.

The above described South-Estonian type of bourdon singing (or similar to that) can be found in the territory of the present-day Latvia, where the former Livonian population dwelled (at the Koiva and Väina river) (Tampere 1977), as well as by Mordvinians, Byelorussians and the West-Russians (Rüütel 1990).

Most of the peculiarities of the described tune-layer (certain rhythmic patterns as well as modal and melodic traits) are distributed widely in the Eastern Baltic region, extending from Karelia and Ingeria up to Byelorussia and the Ukraine (Rüütel 1994). The nearest tune-parallels can be found in Ingeria.

This is the area where the former population of the Eastern Balts (Dniepr-Balts) dwelled. The archaeological data confirm that the Eastern Balts became the neighbours of the Balto-Finnic tribes and Western Balts in the second half of the 1st millennium A.D. and that their culture, as it was represented here in the Eastern Baltic region, was a peculiar mix of the Eastern Baltic, Slavic and Finno-Ugric elements. Thus, it is probable that the discussed tune-layer is related to the described archaeological culture and may also be influenced by the Krivichies who reached the neighbourhood of the Baltic Finns nearly the same time.

According to the archaeological studies, in the region of South-East Estonia and the contemporary Pskov district during IV-IX centuries A.D. a culture evolved which was related to the distribution of barrows. It was formed on the basis of the local Finno-Ugric culture, mixed with the elements of the culture of the Eastern Balts and Krivichies. The carrier of this culture was probably a Finno-Ugric tribe who gave rise to the Võru linguistic and cultural dialect in South-East Estonia. Evidently the discussed song tune layer was a part of the mentioned Võru cultural dialect and was formed at the same time, being complemented with some later Slavic elements (here belong some tune-types, rhythms and refrains which have parallels in Byelorussia, West-Russia and the Ukraine - see: Rüütel 1994: 65-66).

A special branch of the Võru linguistic dialect is retained up to nowadays by the Setu ethnic group in the south-eastern part of Estonia and in the neighbouring area of the contemporary Pskov district. Among the Setus all the above discussed musical layers appear. In addition, one can find here a number of special stylistic and typological peculiarities pertaining to the music and song texts which are not known in other places of Estonia, nor in the neighbouring Russian area. Special scales and rhythmic patterns can be found (Sarv 1980). A number of specific features in songs and music as well as some ethnographic and linguistic peculiarities reveal similarities with the Mordvinians (Rüütel 1990). For example, the Setu polyphony - the most peculiar phenomenon of the Setu folk song (Sarv J. 1880) which is especially similar namely to the Mordvinian polyphony, and has no North-Russian parallels. An observable closeness appears also in the performing style (in a loud, tense voice with a special timbre, gradual rise of the tessiture with the abrupt transition into a lower tonality, etc.). *Example 13 
Archaeologists have discovered a common cultural stratum which was formed in the territory of South Estonia and North Latvia and in the dwelling area of the Volga-Finnic tribes since the VIIVIII century A.D., and which is observable in clothes, adornments, etc. So it is possible that in this period some Finno-Ugric tribes came from the Volga region and populated that Baltic area, mixed here with the former Balto-Finnic population and left some cultural superstrata into their spiritual culture as well. Special peculiarities of the Setu folk song might be caused just by such colonists who assembled the eastern Finno-Ugric influences. It is also possible that certain Finno-Ugric tribes who formerly dwelled inbetween the Balto-Finnic and Volga-Finnic tribes (e.g. Merriams) served as mediators of the cultural contacts between the Volga-Finnic tribes and the South-Estonians.

\section{Two-line refrainless melodies}

In the runo-song tradition of Estonians and other Balto-Finnic peoples two-line refrainless melodies dominate which are in most cases characterised also by a wider tonal-range - a fifth, a sixth. Apparently such tunes represent a more recent musical layer in comparison with the one-line melodies of a narrow ambit. Here one can find melody-types which are typologically (and probably also genetically) related to the one-line tunes and are evidently their elaborations. Still, most of twoline tunes reveal independent melody-types.

A prominent group of melodies represent the tunes which are most characteristic to the NorthKarelian and East-Finnish heroic epic songs. They are characterised by a specific rhythmic pattern $(! ! ! ! ! ! ! !)$ and the so-called question-and-answer form: the first line ends with the second degree and the second line ends with the first degree, i.e. with the tonic. In the first line the tonal range exceeds to the fifth degree while the range of the second line is restricted, as a rule, with the fourth (both lines or one of them can be extended by a subsecond). These melodies have often a minor third but it is not absolute. The major third can occur as well (see: Kolehmainen 1977).

Such a tune-type is usually referred to as a Kalevala-tune. As a matter of fact, it is not by far the only melody-type used in the heroic epic songs and, from the other hand, they are also polyfunctional and are used with other songs as well (e.g. with the wedding songs and lullabies).

The heroic epic of the Kalevala-cycle was probably formed in North-Karelia during a longer period, but it flourished during the era in the end of the 1st millennium and at the beginning of the 2nd millennium A.D. (see: Kuusi 1963). Its distribution is restricted with Karelia, East Finland and Ingeria. It was not known in Estonia. But this melody-style disseminated in Estonia as well; in North Estonia the same melody-types can be met also. The Estonian tune parallels differ mainly in the rhythm (the so called Kalevala-rhythm with two prolonged notes at the end of the line is not popular in Estonia).

Actually, the two-line refrainless tunes with the ambit of a fifth or a sixth constitute the prevailing musical layer of the Estonian runo-songs. In North Estonia they have become dominant not only in the lyrical and narrative songs but also in other song genres. In South Estonia the two-line refrainless melodies were dominant in lyrical and narrative songs while two-line refrain tunes were typical in working songs, wedding and calendar-ritual songs.

The tune-style under question, especially the above described "Kalevala-type" have attained the most attention by researches. From the one hand, this tune group is considered to be formed under the Scandinavian influence (see: Kolehmainen1988); Scandinavian influences are supposed in the later strata of the Kalevala-epics as well. From the other hand, this "Kalevala-tune" has been considered the primeval Finno-Ugric melody-type whereas similar parallels have been found in the 
archaic layer of Hungarian folk songs and in those of all other Finno-Ugrians (Szomjascz-Schiffert 1965).

Actually the "Kalevala-type" represents a wide-spread tune pattern which can be found nearly everywhere. According to one theory such a melodic structure evolved in the Near-East together with the poetical form of the so-called distichon (which consists of two symmetrical verses joined with the end-rhyme) formed in the IV century A.D. and became later popular in the early Islamic culture through which it reached Europe in the Middle Ages (Michaelides 1987).

By the Finno-Ugrians these melodies are evidently older, being formed at least during the period of the flourishing of the Kalevala-epics, may be even earlier. Evidently we have to tackle first of all the stylistic analogues, whose formation process and its impact should be studied separately in the case of each culture before making any final decisions.

The Balto-Finnic music may have received external impact from any direction, and the tune-layer under discussion may also include some tune-patterns borrowed from the neighbouring cultures. Still, in general their primary formation was probably based upon the inner evolution of the former one-line speech-like tunes, while their main structural principle $\mathrm{C} 1>\mathrm{C} 2>\mathrm{F} 1>\mathrm{F} 2 \quad(\mathrm{C}=$ the culminating tone, $\mathrm{F}=$ the final tone) is the same and corresponds to the Balto-Finnic prosodic intonation. The extension of the musical form is probably connected with the typical performance of the runo-songs where the chorus (or the other singer) joins the song-leader at the end of each verse and repeats the same verse-line while also repeating, varying or altering the melody. In older melodies of a small ambit usually slight deviations occur in the 2 nd line; in more recent ones with a larger tonal range the modifications become more noticeable (AA...AA $\left.\mathrm{A}_{1} \ldots \mathrm{AB}\right)$. Example 14

The typology of the two-line melodies is not finished yet. The analysis carried out up to the present show that a lot of different melody-types can be discovered despite of the external stylistic similarity. So in the Jõhvi parish (North Estonia) 8 two-line tune-types were established (Tuvi 1992).

Beside the above described monodic tunes of the narrative character, another style occurs which is related to the instrumental music. Here belong, first of all, tunes which derive from the bagpipe pieces. ${ }^{* \mathrm{C} 1}$ Similar tune-patterns are met in triple metre dance song tunes and in narrative or lyrical runo songs - often humorous men's songs, sometimes also other genres, e.g. the wedding-tunes of the Mustjala parish in western Saaremaa (Rüütel 1980). *Example 15. Wedding song

Among the latest two-line refrainless runo-song tunes are included the samples with a developed harmonic structure, i.e. those which are based on the functions of the tonic, dominant and subdominant and thus belong to the major-minor modal system characteristic of the newer Estonian song style with the end-rhyme and strophic structure (see: Rüütel 1980A). The latter does not belong to the subject of this paper, and the same concerns a small amount of runo-song tunes with the four-line strophic form which are borrowed from the newer songs or developed according to their patterns.

\section{Conclusions}

In the Estonian runo-songs the next tune-layers can be distinguished:

1. The most ancient one-line refrainless polyfunctional tunes with a narrow tonal range, a descending contour and a recitative character whose distribution area coincides in general with the oldest regions of resident agriculture of North and West Estonia, dating from the 1st millennium 
B.C. and the beginning of the 1st millennium A.D. They were probably formed together with the runo-verse form. Similar melodic types predominate also in the oldest Votic songs, parallels can be found in the oldest song-layers of the other Finno-Ugric peoples, and also in laments, spells and other, probably pre-song genres.

2. One-line swing-song tunes with the descending-ascending contour and special rhythms spread in a restricted area of North Estonia. Their formation may be connected with the development of the cultural and linguistic peculiarities of the Estonian tribes in the first centuries A.D. Later on, a number of new one- and two-line swing-tunes were formed on their basis.

3. One-line refrain tunes with a narrow tonal range which were characteristic of the South-Estonian working, ceremonial and game songs, and were formed in the first centuries A.D. at the latest as a symbiosis of the South-Estonian and Latvian (Baltic) songlore.

4. In South-East Estonia (as well as in Ingeria) one and two-line tunes can be found where the metre, rhythm and melodic structures differ greatly from the structure of a runo-song verse and melodies and which probably derive from some other ethnic culture. The formation of such tunes may be explained by the superstratum of the culture of the East-Baltic and Slavic tribes (Krivichies) who settled in the neighbourhood of the Balts and Baltic Finns mostly in the 2nd half of the 1st millennium A.D. This tune-layer includes also some later Slavic influences.

5. Two-line refrainless tunes with an ambit of a fifth or sixth which prevail in the runo-songs of all the Balto-Finnic peoples, including the Karelian epic songs of the Kalevala-cycle. Here belong also a melody-pattern which is known in folk music studies as the Kalevala-tune. We are dealing with melodies which are wide-spread in Europe as well as in other continents and whose formation evidently can not be explained by a common genesis. By the Estonians and other Baltic Finns they were probably formed at the beginning of the 2nd millennium A.D. on the grounds of the internal development of the melodies of the first layer. To a certain extent, some European, including Scandinavian influences may be considered.

The newer folk music give more evidence to cultural contacts rather than to ethnic relations, as was the case with the older layers.

\section{Comment}

*C1 Ancient bagpipe tunes with triple metre and specific rhythmic patterns were popular in North and West Estonia and by the Estonian Swedes. It represents probably a style of instrumental music from the early Middle Ages, with an area of distribution extending from Estonia to Scandinavia and up to Ireland (though here another bagpipe tune-style prevailed). In Estonia a special dance-song style disseminated in the XVIII and the XIX centuries, which was formed on the basis of these bagpipe tunes. Their rhythm caused the formation of a very special verse form which differ greatly from the runo-verse (Rüütel 1971). These songs contain some elements of the runo-song form (e.g. alliteration) as well as of the newer folk song (the end-rhyme) and belong to the so-called transitional folk song form. 


\section{References}

Ariste, P. 1956. Läänemere keelte kujunemine ja vanem arenemisjärk. Eesti rahva etnilisest ajaloost. Tallinn.

Chekanowska, A. 1977. On the Theory and Definitions of Melodic Type. 1976 Yearbook of the IFMC. Vol 8.

Elschekova, A. 1966. Strukturelle Frühformen slavischer Volksmusik. Anfange der slavischen Volksmusik. Bratislava.

Bendorfs, V. 1981. Folk'lornyi sbornik Andreia Iur'iana "Ligotnes" - melodii pesni na Ivana Kupala s pripevom Ligo /1894/. Faksimil'naia reproduktsia s kommentariem /na latshkom i russkom iazykakh/. Andreia Iur'ian v muzyke i zhizni naroda. Sost. A. Klotin'.

Kolehmainen, I. 1977. Kalevalasävelmien musikologista syntaksia. Progradu-tutkielma musiikkitieteessä ja sivulaudaturtyö suomalaisen ja vertailevan kansanrunouden tutkimuksessa. Helsinki.

Kuusi, M. 1963. Suomen kirjallisuus I. Kirjoittamaton kirjallisuus. Keuruu.

Lach, R. 1929. Eesti rahvalaulu arengulooline missioon. Eesti Muusika Kuukiri I. Tartu.

Laurinkiene, N. 1982. Semantika i poetika litovskikh kalendarnykh pesen. Vilnius.

Ling, J., Jersild, M. 1965. A Method of Catalouging Vocal Folk Music. A description of the system used at the Svenskt Visarkiv. Särtryck ur ARV Stockholm.

Macievsky, M. 1980. O finno-ugorskikh reliktakh i patalleliakh v russkoi narodnoi instrumaenta'noi muzyke. Finno-ugorskii muzykal'nyi fol'klor i vzaimosvjazi s sosednimi kul'turami. Tallinn.

Michaelides, N. 1987. Muzykal'naia kul'tura Blizhnego Vostoka kak nositel' odnogo iz vazhneishikh elementov, formiruiushtshikh melodiu klassitcheskoi Evropeiskoi muzyki. Traditsii muzykal'nykh kul'tur narodov Blizhnego, Srednego Vostoka i sovremennost'. Moskva.

Pelinski, R. 1981. La musique des Inuit du Caribou. Montreál.

Pino, V. \& Sarv, V. 1991. Setu surnuitkud I. Tallinn.

Pino, V. \& Sarv, V. 1992. Setu surnuitkud II. Tallinn.

Rüütel, I. 1970. Vadja rahvalauludest ja nende suhetest eesti laulutraditsiooniga.

Läänemeresoomlaste rahvakultuurist. Tallinn.

Rüütel, I. 1971. Eesti uuema rahvalaulu varasemast arengujärgust. Paar sammukest eesti kirjanduse uurimise teed VII. Tartu.

Rüütel, I. 1977. Vadja rahvamuusika tüpoloogia ja stiilid. Muzykal'noie nasledie finno-ugorskikh narodov. Tallinn.

Rüütel, I. 1980. Mustjala regiviiside tüpoloogia. Ars Musicae Popularis 1. Tallinn.

Rüütel, I. 1980A. Melodii narodnykh pesen pozdneishego proizhozhdenia. Estonskii fol'klor.

Tallinn.

Rüütel, I. 1981. Typology of Estonian Runo-Tunes: Experiment and Some Results. Preprint KKI-18. Tallinn.

Rüütel, I. 1982. Oudekki Figurova vadja rahvaviisid. Läänemeresoomlaste etnokultuuri küsimusi. Tallinn.

Rüütel, I. 1986. Tipologia, struktura i razvitie estonskikh odnostrotshnykh svadebnykh napevov. Muzyka v obriadakh i trudovoi deiatel'nostifinno-ugrov. Tallinn.

Rüütel, I. 1986 A. Odnostrotshnyie uzkoob"iemnyie svadebnyie napevy v obshtshem kontekste estonskikh runitsheskikh pesen. Muzyka v svadebnom obriade finno-ugorskikh i sosednykh narodov. Tallinn.

Rüütel, I. 1990. Die Schichten des Volkslieds der Setukesen und ihre ethnokulturellen Hintergründe. Finnisch-ugrischen Forschungen. Vol. XLIX.

Rüütel, I. 1994. Istoritsheskie plasty estonskoi narodnoi pesni v kontekste etnitsheskikh otnoshenii. Ars Musicae Popularis 12. Tallinn. 
Rüütel, I. \& Haugas, K. 1987. Metod razpoznavania meloditsheskikh tipov i opredelenia tipologitsheskikh grupp. Kolitshestvennyie metody v muzykal'noi fol'kloristike i muzykoznania.

Moskva.

Rüütel, I. \& Remmel, M. 1980. Opyt natatsii i issledovania vepskikh pritshitanii. Finno-ugorskii muzykal'nyi fol'klor i vzaimosvjazi s sosednymi kul'turami. Tallinn.

Salve, K. \& Sarv, V. 1987. Setu lauludega muinasjutud. Tallinn.

Sarv, J. 1880. Rasshifrovka setuskogo mnogogolosia pri pomostshi mnogokanal'noi studiinoi apparatury. Finno-ugorskii muzykal'nyi fol'klor i vzaimosvjazi s sosednimi kul'turami. Tallinn.

Sarv, V. 1880. O zakonomernostiakh stroienia zvukoriadov i ritmiki v setuskom muzykal'nom fol'klore (na materale pesen odnoi zapevaly). Finno-ugorskii muzykal'nyi fol'klor $i$ vzaimosvjazi s sosednimi kul'turami. Tallinn.

Sarv, V. 1986. Vidy setuskikh pritshitanii i ikh muzykal'nye osobennosti. Muzyka v obriadakh $i$ trudovoi deiatel'nosti finno-ugrov. Tallinn.

Szomjascz-Schiffert, G. 1965. Der Kalevala-Typ in den gemeinsamen Melodien der finno-

ugrischen Völker. Congressus Secundus Internationalis Fenno-Ugristarum. Helsinki, 23-28. VIII. 1965. Pars II. Helsinki.

Tampere, H. 1956. Mõningaid eestlaste etnilise ajaloo küsimusi suulise rahvaloomingu valgusel. Eesti rahva etnilisest ajaloost. Tallinn.

Tampere, H. 1956A. Eesti rahvalaule viisidega I. Tallinn.

Tampere, H. 1958. Eesti rahvalaule viisidega III. Tallinn.

Tampere, H. 1960. Eesti rahvalaule viisidega II. Tallinn.

Tampere, H. 1977. Mõned mõtted liivi rahvalaulust. Soome-ugri rahvaste muusikapärandist.

Tallinn.

Tedre, Ü. 1969. Eesti rahvalaulud. Antoloogia I. Tallinn.

Toi, R. 1982. Swing-Songs in Estonian Folk Songs. Folkloristica: Festschrift for Felix J. Oinas. Indiana University Uralic and Altaic Series, Volume 141. Bloomington. Indiana.

Tuvi, E. 1992. Kokamägi, H. \& Tuvi, E. Jõhvi ja Iisaku kihelkonna regilauludest ja -viisidest. IdaVirumaa rahvakultuurist. (Koost. ja tead. toim. I. Rüütel). Tallinn.

Vargyas, L. 1981. The First Phase of Development of Finno-Ugric Music. Congressus Quintus Internationalis Fenno-Ugristarum. Turku. 20.-27. VIII 1980. Pars VIII, Turku.

Vilkuna, K. 1946. Työ ja ilonpito. Helsinki.

Virtanen, L. 1987. Suomalaisen ja virolaisen kansanrunouden suhteista. Viron veräjät. Tietolipas 105. Hämeenlinna.

Vissel, A. 1986. Estonskie pastusheskie pesni (vidy, regoinal'nyie i muzykal'nyie osobennosti). Muzyka v obriadakh i trudovoi deiatel'nosti finno-ugrov. Tallinn.

\section{Examples}

1. Wedding shout. RKM, Mgn. II 1576 b - Theodor Saar, etc., Kihnu (1968).

2. Rooster's crow. RKM, Mgn. II 3311 (15) - Marta Mäesalu, Häädemeeste (1979).

3. Roosters of rich men and a poor man. RKM, Mgn. II 3311 (16) - Marta Mäesalu, Häädemeeste (1979).

4. Spinning wheels of the diligent and the lazy girl. RKM, Mgn. II 3311 (26) - Marta Mäesalu, Häädemeeste (1979).

5. Charm against snake-bite. RKM, Mgn. II $520 \mathrm{~h}$ - Liisa Kümmel, Tori (1961).

6. Backing a bun (children's amusement song). RKM, Mgn. II 3311 (3) - Marta Mäesalu, Häädemeeste (1979).

7. Hallo, black grouse! (Chain song). RKM, Mgn. II 163 d - Ida Pino, Setu (1959).

8. Wedding song. ERA, P1. 86 B1 - Miina Lambot and Anna Paalberg, Kuusalu (1938). 
9. Swing-song. RKM, Mgn. II 1022 b - Lisette Kautlenbach, Järva-Madise (1965).

10. Song of Midsummer. ERA, P1. 49 A2 - Marie Sepp, Kolga-Jaani (1937).

11. The bird consoles the orphan (lyrical song). RKM, Mgn. II 2927 (11) - Ella Hummel, Rõuge (1977).

12. The purchased voice (lyrical song). ERA, Fon 4a - Ann Kolatsk, Eeva Valner, Karula (1912).(=H. Tampere, Eesti rahvalaule viisidega V. Tallinn 1965. P. 46. Notated by A.O. Väisänen).

13. The bride's lament. RKM, Mgn. II 2424 f - Olga Laanetu (1973). (=Soomeugrilaste rahvamuusika ja naaberkultuurid. Tallinn 1980. P. 138. Notated by V. Sarv).

14. A swindler suitor (lyrical song). RKM, Mgn. II 734a - Kristjan Kiviloo. Kuusalu (1962).

15. Wedding song. RKM, Mgn. II 1650g - Mare Pook, Mustjala (1963). 